\title{
Physiological and behavioural responses of different life stages of a serpulid polychaete to hypoxia
}

\author{
Y. S. Leung ${ }^{1}$, P. K. S. Shin ${ }^{1}$, J. W. Qiu ${ }^{2}$, P. O. Ang ${ }^{3}$, J. M. Y. Chiu ${ }^{4}$, V. Thiyagarajan ${ }^{4}$ \\ S. G. Cheung ${ }^{1, *}$ \\ ${ }^{1}$ Department of Biology and Chemistry, City University of Hong Kong, Tat Chee Avenue, Kowloon, Hong Kong, SAR \\ ${ }^{2}$ Department of Biology, Hong Kong Baptist University, Hong Kong, SAR \\ ${ }^{3}$ School of Life Sciences, Chinese University of Hong Kong, New Territories, Hong Kong, SAR \\ ${ }^{4}$ School of Biological Sciences, The University of Hong Kong, Pokfulam, Hong Kong, SAR
}

\begin{abstract}
Hypoxia has become a major threat to coastal marine ecosystems worldwide. Among various groups of marine invertebrates, sessile ones are more susceptible to hypoxia since they cannot move away from hypoxic waters. The serpulid polychaete Hydroides elegans Haswell, 1883 is a fast-proliferating, dominant, sessile-fouling species in the tropical Pacific, which includes Hong Kong. We studied the effects of hypoxia on the fertilization success, embryogenesis and physiological and behavioural responses in both larval and adult stages of $H$. elegans. Results showed that fertilization success was reduced and embryogenesis was retarded at a dissolved oxygen (DO) level of $2 \mathrm{mg} \mathrm{O}_{2} \mathrm{l}^{-1}$. At this DO level, the swimming velocity of the $2 \mathrm{~d}$ old larvae significantly increased, which may serve as an escape response. $H$. elegans showed a very high tolerance to hypoxia in both larval and adult stages, as indicated by the 24 and $48 \mathrm{~h}$ lethal DO concentation $\left(\mathrm{LC}_{50}\right)$. However, the respiration rate and clearance rate of adult $H$. elegans were significantly reduced at $2 \mathrm{mg} \mathrm{O} \mathrm{O}_{2} \mathrm{l}^{-1}$. Partial recovery was observed $2 \mathrm{~d}$ after normoxia was resumed. Previous studies have demonstrated that adult $H$. elegans suffer from high mortality and that there are no new recruits in summer when the temperature is high and DO concentration low. The results are interpreted as the effect of low salinity. Our study has strengthened the notion that low salinity contributes to adult mortality in summer; however, the lack of summer recruitment is possibly a result of the combined effect of low salinity and hypoxia.
\end{abstract}

KEY WORDS: Hypoxia $\cdot$ Hydroides elegans $\cdot \mathrm{LC}_{50} \cdot$ Embryogenesis $\cdot$ Respiration rate $\cdot$ Clearance rate

\section{INTRODUCTION}

Hypoxia, a condition of depleted dissolved oxygen (DO) content in a body of water to an extent that compromises the physiology and survival of aquatic organisms, can be a natural phenomenon attributed to temperature and salinity stratification in the water column. However, it is often caused by anthropogenic input of nutrients and organic matter into waters with poor circulation due to intensive farming, application of fertilizers and discharge of domestic wastewater (Diaz \& Rosenberg 1995, Rabalais et al. 2002, Wu 2002). The problem of hypoxia is expected to increase in severity and frequency of occurrence in the future with the increase in human activities and intensification of global warming (Nixon 1990, UNEP 1991, Wu 2002). 
Hypoxia has a significant effect on the benthic community. Most benthic species die within a few days when the DO level reaches $<1 \mathrm{mg} \mathrm{O}_{2} \mathrm{l}^{-1}$ (Llansó 1992, Diaz \& Rosenberg 1995, 2008). The death of benthic species alters the community structure as only few tolerant, opportunistic species thrive under hypoxia (Dauer 1993, Diaz \& Rosenberg 1995). Furthermore, hypoxia often coincides with the spawning or larval settlement periods of many benthic organisms, resulting in detrimental effects on the benthic community (Rosenberg \& Loo 1988). Even when the hypoxic condition is non-lethal, the physiology and growth of most benthic species are still compromised (Rosenberg et al. 1991, Breitburg 2002). Some polychaetes may leave their burrows and move to the sediment surface, whereas bivalves extend their siphons above the sediment-water interface to obtain oxygen rich waters (Pihl et al. 1992, Nilsson \& Rosenberg 1994). Such behavioural responses to hypoxia may expose the organisms to higher predation risk (Nestlerode \& Diaz 1998, Taylor \& Eggleston 2000).

Many hypoxia studies have been conducted on benthos living in soft sediment, but little is known about the effects of hypoxia on sessile benthos living on hard substrate although they also may experience hypoxia during their larval development, settlement and adult stages. For example, Baker \& Mann (1992) revealed that the percentage settlement of oyster Crassostrea virginica was reduced at a DO level of $1.5 \mathrm{mg} \mathrm{O}_{2} \mathrm{l}^{-1}$ (38\% saturation) compared to normoxia (79\% saturation), whereas nearly no settlement was observed in anoxic conditions (4\% saturation). Desai \& Prakash (2009) demonstrated that the naupliar feeding rate and oxygen consumption of barnacle Balanus amphitrite was significantly reduced in hypoxic conditions, implying a negative effect on larval development.

We examined the effects of hypoxia on the survival, feeding and behavioural responses on different life stages of the serpulid polychaete Hydroides elegans (Haswell, 1883), a widespread, gregarious, tubebuilding species characterized by rapid growth, proliferation and colonization and a short life cycle (Qiu \& Qian 1997, 1998, Carpizo-Ituarte \& Hadfield 1998). This species is a nuisance to many man-made structures, such as ship hulls, buoys, nettings in fish farms and water-intake pipes of power plants (Godwin 2003), incurring huge economic loss due to the maintenance of these structures, including regular cleaning and application of anti-fouling agents (Townsin 2003). In Hong Kong, the settlement and growth of this species is seasonal, occurring only in fall to early spring when water temperature is relatively low and DO concentration relatively high (Qiu \& Qian 1997, 1998). The massive recruitment of $H$. elegans during the winter season results in its dominance over other fouling organisms, such as barnacles, sponges and mussels, in Hong Kong. In summer when the temperature is high and DO concentration low, however, the adults suffer from high mortality and there are no new recruits (J. W. Qiu pers. obs.). A previous study (Qiu \& Qian 1997) indicated that the embryos and larvae of $H$. elegans are very sensitive to low salinity, which can occur during the summer monsoon in Hong Kong. However, it cannot be ruled out that hypoxia, prevailing in Hong Kong during summer months in harbours and protected fish farms in local waters, also contributes to the mass mortality and lack of recruitment of $H$. elegans. In a routine monthly monitoring program conducted by the Environmental Protection Department, Hong Kong SAR Government (http://epic.epd.gov.hk/ca/uid/marine historical/p/1), bottom water in Tolo Harbour, Hong Kong, where $H$. elegans is abundant, suffered from hypoxia in summer (July to August) in the past $4 \mathrm{yr}$ between 2008 and 2011. From 8 samplings, 4 had a DO of 0.6 to $2.1 \mathrm{mg} \mathrm{O}_{2} \mathrm{l}^{-1}$ or (9 to $31 \%$ saturation). The occurrence of red tides associated with eutrophication contributes to hypoxia. From 1975 to 2011, 329 cases of red tide were reported in Tolo Harbour, or $37 \%$ of all the cases reported in Hong Kong (www. afcd.gov.hk/english/fisheries/hkredtide/redtide.html). In addition, hypoxia may be worse in warming waters in the future due to combined effects from decreased oxygen solubility and increased respiration rates (Boesch 2008). Our study can thus enhance the understanding of the tolerance and adaptive strategies of $H$. elegans under hypoxia and may help explain the seasonal life-history pattern of the species in tropical marine waters.

\section{MATERIALS AND METHODS}

\section{Collection and rearing}

Adult Hydroides elegans were collected from a fish farm in Yung Shue O $\left(22^{\circ} 19^{\prime} \mathrm{N}, 114^{\circ} 16^{\prime} \mathrm{E}\right)$ and kept under laboratory conditions (temperature: $20 \pm 1^{\circ} \mathrm{C}$, DO: $8.5 \pm 0.2 \mathrm{mg} \mathrm{O}_{2} \mathrm{l}^{-1}$, salinity: $33 \pm 1$ and $\mathrm{pH}: 7.66$ \pm 0.1 ). The seawater was renewed weekly, and the tubeworms were fed daily with $\sim 1 \times 10^{5}$ cells ml $^{-1}$ of Isochrysis galbana (Qiu \& Qian 1998). Illumination was provided with a light cycle of $14 \mathrm{~h}$ light:10 h dark. 


\section{Larval culture}

Adult Hydroides elegans with similar tube lengths (1.8 to $2.5 \mathrm{~cm}$ ) were selected for spawning, and each individual was placed in a petri dish $(55 \mathrm{~mm}$ in diameter) with $\sim 5 \mathrm{ml}$ filtered seawater (FSW). The calcareous tube near the abdominal region of the $H$. elegans was carefully broken with a pair of forceps under a dissecting microscope to induce spawning, and the eggs (orange) or sperm (creamy white) were released immediately from the abdomen. The eggs from 5 females and sperm from 8 males were collected and transferred with pipettes into separate beakers filled with $\sim 3 \mathrm{ml}$ FSW. The eggs and sperm suspensions were mixed in a $250 \mathrm{ml}$ beaker filled with $150 \mathrm{ml}$ FSW. The larvae hatched $\sim 12 \mathrm{~h}$ after fertilization, and their swimming behaviour was observed under a compound microscope. Larvae were fed daily with $\sim 1 \times 10^{5}$ cells $\mathrm{ml}^{-1}$ of Isochrysis galbana, and FSW was renewed once every $3 \mathrm{~d}$.

\section{Control of DO levels in the experiment}

The desired DO levels were achieved by pumping an appropriate mixture of nitrogen and air into the system. The flow rate of the gases was controlled by digital flow meters (Voegtlin GCR-B3SA-BA20). The DO level in the seawater was monitored by the Stable Optical Oxygen System (TauTheta Instruments, SOO-100-OEM) to maintain the desired DO levels. Normoxia was maintained by pumping air only. The tubeworms were acclimated for $1 \mathrm{wk}$ prior to experimentation. A heating bath circulator maintained the temperature for all of the experiments at $28^{\circ} \mathrm{C}$. This is the average summer temperature of bottom water in Hong Kong (EPD 2007). The salinity for all of the experiments was maintained at $33 \pm 1$.

\section{Expt 1: embryonic development under hypoxia}

The petri dishes used in the present study were specially designed such that desired oxygen levels could be maintained throughout the experiment. The upper lid of each petri dish was attached to an inverted funnel, which was connected to the gas supplying system. Several holes were drilled in the lid such that gas with a desired oxygen concentration could enter the dish continuously. Sperm from 7 males was pipetted into a $25 \mathrm{ml}$ beaker containing $1 \mathrm{ml}$ FSW. An adequate amount of eggs from 4 females was pipetted into a small petri dish (BD Falcon, $35 \mathrm{~mm}$ in diameter $\times 10 \mathrm{~mm}$ in height). Prior to adding the sperm suspension, the DO level of the FSW in the petri dish and sperm suspension was adjusted to one of the following DO levels: 2, 4 or $6 \mathrm{mg} \mathrm{O} \mathrm{l}^{-1}$. About $1 \mathrm{ml}$ sperm suspension was added uniformly into the petri dish, and a timer was switched on. Micrographs were taken at 100× magnification at Minute 5, 30, 60, 90, 120, 150, 180 and 210 after adding the sperm suspension. About 80 to 100 eggs were enumerated, and their embryonic stage was identified. As it is very difficult to differentiate various embryonic stages beyond the 16 cell stage accurately, these stages were pooled together as blastula stage. Five replicates were taken for each DO level. The percentage of eggs reaching a particular embryonic stage was computed as follows:

No. of eggs reaching a particular embryonic stage

$$
\text { Total number of eggs observed }
$$

To estimate the developmental rate, the mean embryonic stage at each sampling time was calculated using the formula:

$$
\text { Mean embryonic stage }=\sum n_{i} \times p_{i}
$$

where $n$ is the number of eggs in the ith embryonic stage, and $p$ is the proportion of that $i$ th embryonic stage. Since the developmental time between each stage is different, a number was assigned to each embryonic stage for the calculation of the developmental rate (1: 1 cell stage, 2: 2 cell stage, 3: 4 cell stage, 4: 8 cell stage, 5: 16 cell stage and 6: blastula stage). The 3 cell stage represented abnormal cell division and contributed to a very small proportion of the embryos; thus, this stage was ignored in the calculation of the developmental rate.

Some of the hatched trochophore larvae were selected and fixed by adding a small amount of ethanol. They were then immediately photographed under a compound microscope. The diameter at the prototroch stage of 15 ind. was measured as the size at hatching (Henderson \& Strathmann 2000).

\section{Expt 2: hypoxia tolerance of larvae}

Hydroides elegans larvae (30 ind., 2 d old) were pipetted into a glass vial containing $30 \mathrm{ml} \mathrm{FSW} \mathrm{and}$ maintained at one of the following DO levels: 0.1, $0.15,0.25,0.5,1,2,4$ or $6 \mathrm{mg} \mathrm{O}_{2} \mathrm{l}^{-1}$. The experiment lasted for $48 \mathrm{~h}$, and mortality was recorded at Hour 24 and Hour 48. An individual was considered dead if it showed no ciliary movement or no response to tactile stimulus. The seawater was renewed daily, 
and the larvae were fed with $2 \mathrm{ml}$ suspension of Isochrysis galbana $\left(1 \times 10^{5}\right.$ cells $\left.\mathrm{ml}^{-1}\right)$. Three replicates were prepared for each DO level.

\section{Expt 3: swimming velocity of larvae under hypoxia}

Hydroides elegans larvae (60 ind., 2d old) were pipetted into a petri dish $(55 \mathrm{~mm} \varnothing)$ with seawater maintained at a DO level of 2, 4 or $6 \mathrm{mg} \mathrm{O}_{2} \mathrm{l}^{-1}$. The petri dish was placed under a compound microscope (Axioplan 2 imaging, ZEISS) equipped with a video camera to observe the swimming behaviour. We analysed 3 different types of larval swimming velocity, namely curvilinear velocity (VCL), straight-line velocity (VSL) and average path velocity (VAP), using the CRISMAS sperm motility analysis system (Image House A/S) (Chan et al. 2008). VCL is defined as the time-average velocity of a larva along its actual trajectory and considered the actual swimming velocity. VSL is the time average velocity of a larva along a straight line between its first detected and last detected position and considered as the dispersal velocity. VAP is the velocity with the distance calculated by adding straight-line values between every 2 frames. We selected 20 larvae randomly from each petri dish for measurement. Triplicates were prepared for each DO level.

\section{Expt 4: hypoxia tolerance of adults}

Hydroides elegans (10 ind., adult) with similar tube length $(2.0 \pm 0.3 \mathrm{~cm})$ were selected and maintained in a glass cylinder containing $170 \mathrm{ml} \mathrm{FSW}$ at a DO level of $0.14,0.25,0.35,0.5,0.75,1,1.5,2,4$ or $6 \mathrm{mg} \mathrm{O}_{2} \mathrm{l}^{-1}$. The experiment lasted for $48 \mathrm{~h}$, and mortality was recorded at Hour 24 and Hour 48. Individuals showing no response to food and light stimuli for $30 \mathrm{~min}$ were considered dead. Seawater was renewed daily. Triplicates were prepared for each DO level.

\section{Expt 5: respiration rate of adults under hypoxia}

Adult Hydroides elegans with tube lengths of $2.0 \pm$ $0.3 \mathrm{~cm}$ (mean $\pm \mathrm{SD}$ ) were maintained in a glass cylinder with $170 \mathrm{ml} \mathrm{FSW} \mathrm{at} \mathrm{a} \mathrm{DO} \mathrm{level} \mathrm{of} \mathrm{2,} 4$ or $6 \mathrm{mg} \mathrm{O}_{2}$ $\mathrm{l}^{-1}$. For normoxia treatment $\left(6 \mathrm{mg} \mathrm{O}_{2} \mathrm{l}^{-1}\right)$, the DO level was kept constant from Day 1 to Day 5. For the other 2 treatments, the DO level was $6 \mathrm{mg} \mathrm{O}_{2} \mathrm{l}^{-1}$ on Day 1 but reduced to either 2 or $4 \mathrm{mg} \mathrm{O}_{2} \mathrm{l}^{-1}$ on Days 2 and 3 and returned to $6 \mathrm{mg} \mathrm{O}_{2} \mathrm{l}^{-1}$ on Days 4 and 5 .
The individuals were fed Isochrysis galbana, and the seawater was renewed daily. From Day 1 to Day 5, oxygen consumption was measured every $24 \mathrm{~h}$ before feeding. From each treatment, 10 ind. were transferred carefully into a syringe filled with $25 \mathrm{ml}$ FSW, and the syringe was sealed for $60 \mathrm{~min}$. Initial and final DO levels in each syringe were measured by an optical oxygen sensor (TauTheta S00-100). We prepared 6 replicates for each DO level.

\section{Expt 6: clearance rate of adults under hypoxia}

Similar to Expt 5, 3 DO treatments $(2,4$ and $6 \mathrm{mg}$ $\mathrm{O}_{2} \mathrm{l}^{-1}$ ) were prepared. For normoxia treatment (6 mg $\mathrm{O}_{2} \mathrm{l}^{-1}$ ), the DO level was kept constant from Day 1 to Day 5. For the other 2 treatments, the DO level was $6 \mathrm{mg} \mathrm{O} \mathrm{I}^{-1}$ on Day 1 but reduced to either 2 or $4 \mathrm{mg}$ $\mathrm{O}_{2} \mathrm{l}^{-1}$ on Days 2 and 3 and returned to $6 \mathrm{mg} \mathrm{O} \mathrm{O}^{-1}$ on Days 4 and 5. On each day, clearance rate was determined immediately after respiration rate determination. Owing to the small size of the individuals, for each replicate, 20 ind. from each treatment were maintained in a glass container filled with $80 \mathrm{ml}$ FSW with an initial concentration of $5 \times 10^{4} \mathrm{cell} \mathrm{ml}^{-1}$ of Isochrysis galbana. This concentration had been determined in a preliminary experiment at which the clearance rate was highest. The individuals were allowed to feed for $1 \mathrm{~h}$. To measure the algal concentration, a $1 \mathrm{ml}$ seawater sample was taken from each container every $20 \mathrm{~min}$ and algae were counted using a haemocytometer. Before counting the algae were fixed by adding $1 \%(\mathrm{v} / \mathrm{v})$ Lugol's solution to the glass container. We prepared 6 replicates for each DO level. The clearance rate was computed after Coughlan (1969):

$$
\mathrm{CR}=\left(\frac{V}{t}\right) \times \ln \left(\frac{C_{0}}{C_{t}}\right)
$$

where $\mathrm{CR}$ is the clearance rate $\left(1 \mathrm{ind} .^{-1} \mathrm{~h}^{-1}\right), V$ is the volume of seawater (1), and $C_{0}$ and $C_{t}$ are the initial and final algal concentrations.

\section{Statistical analyses}

The percentage data were arcsine-transformed prior to data analysis (i.e. fertilization success and mortality) (Townend 2002). One-way ANOVA with Tukey's test for pair-wise multiple comparisons at $\mathrm{p} \leq$ 0.05 was applied to examine the effect of DO on fertilization success, size at hatching, swimming velocity and mortality. Two-way repeated measures 
ANOVA was applied to examine the effect of DO and time on respiration rate and clearance rate. Normality and equal variance were tested by KolmogorovSmirnov and Levene's test, respectively. Nonparametric ANOVA on ranks was employed if the assumptions of normal distribution or equal variance were violated, even after transformation. A nonparametric Kruskal-Wallis test was applied to test the effect of DO on developmental rate, indicated by mean embryonic stage. The statistical analysis was conducted using software SPSS 16.0 for Windows. Values of 24 and $48 \mathrm{~h}$ lethal DO concentration ( $\mathrm{LC}_{50}$ ) of adult Hydroides elegans and larvae were calculated using the ToxCalc software (Tidepool Scientific Software).

\section{RESULTS}

\section{Expt 1: embryonic development under hypoxia}

The effect of DO on the percentage of each embryonic stage at different times is shown in Fig. 1. The first cell division occurred at $\sim 30$ min post fertilization in the DO 6 and DO 4 treatments but was delayed to $60 \mathrm{~min}$ in the DO 2 treatment. Cell division seemed arrested after $150 \mathrm{~min}$ at the DO 2 treatment. For the DO 4 and DO 6 treatments, at $210 \mathrm{~min}$, $\sim 95 \%$ of the fertilized eggs developed into blastula stage. The proportion of 1 cell stage at $210 \mathrm{~min}$ in the DO 2 treatment was significantly higher than in the DO 4 and DO 6 treatments (1-way ANOVA, $F=29.7$, $\mathrm{p}<0.001$ ), while the values in the DO 4 and DO 6 treatments were comparable. Mean embryonic stage, an indicator of developmental rate, at different DO levels is shown in Fig. 2. The eggs from the DO 4 and DO 6 treatments divided significantly faster than those from DO 2. The size of trochophore larvae (mean $\pm 1 \mathrm{SD}$ ) for the DO 6, 4 and 2 treatments was $58.1 \pm 3.34,58.6 \pm 3.65$ and $59.7 \pm 4.54 \mu \mathrm{m}$, respectively, and did not significantly differ among treatments (1-way ANOVA, $F=0.644, \mathrm{p}>0.05$ ).

\section{Expt 2: hypoxia tolerance of larvae}

The 24 and $48 \mathrm{~h}$ mortalities of $2 \mathrm{~d}$ old Hydroides elegans larvae at various DO levels are shown in Fig. 3. Mortality was not significantly different among various DO levels between 6 and $0.5 \mathrm{mg} \mathrm{O}_{2} \mathrm{l}^{-1}$ at $24 \mathrm{~h}$ and between 6 and $1.0 \mathrm{mg} \mathrm{O}_{2} \mathrm{l}^{-1}$ at $48 \mathrm{~h}$. Mortality was higher when the DO level was further reduced, and highest for $0.1 \mathrm{mg} \mathrm{O}_{2} \mathrm{l}^{-1}$ at 24 and $48 \mathrm{~h}$. The $24 \mathrm{~h}$
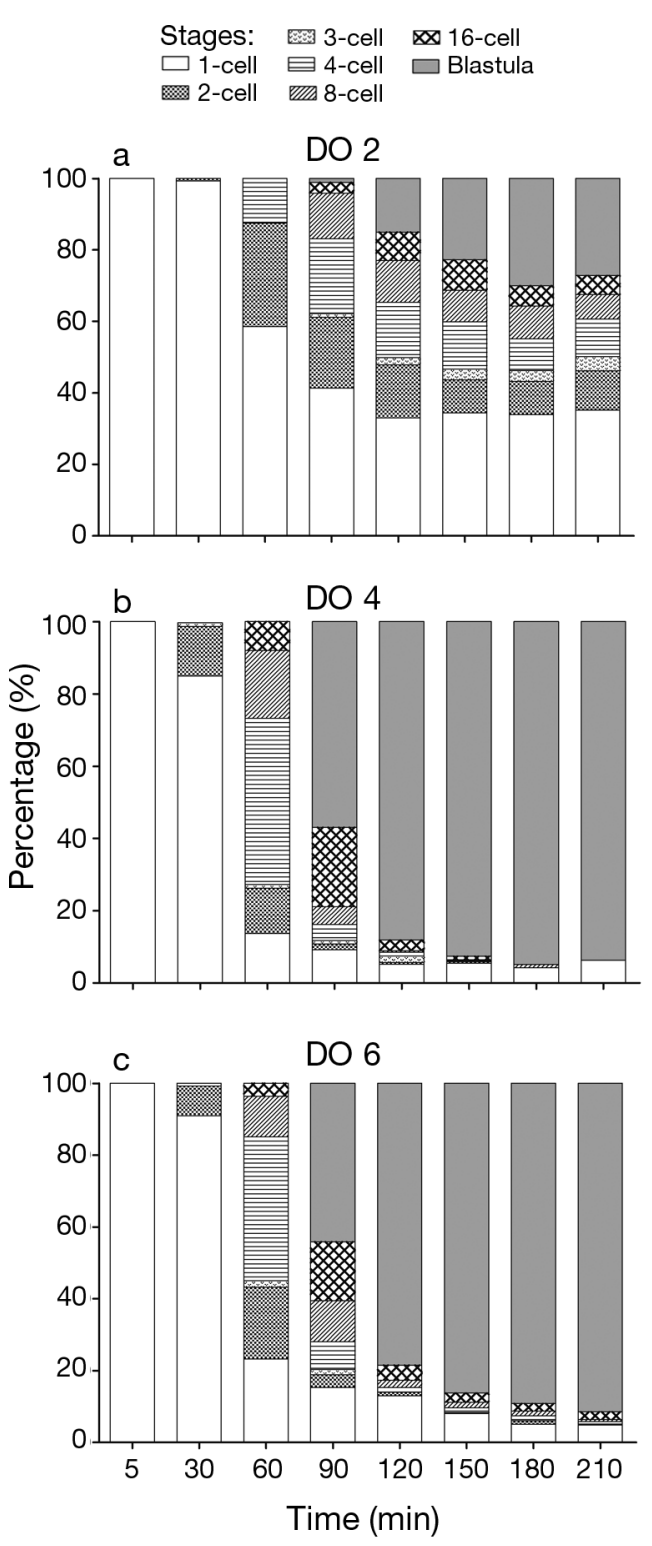

Fig. 1. Hydroides elegans. Effect of reduced dissolved oxygen concentration (DO, mg $\mathrm{O}_{2} \mathrm{l}^{-1}$ ) on the development of embryos, depicted as the mean percentage of each embryonic stage at different sampling times (min) for (a) DO 2, (b) DO 4 and (c) DO 6 treatment ( $\mathrm{n}=5$ each). The percentage of 1 cell stage at Minute 210 reflects the fertilization success

$\mathrm{LC}_{50}$ and $48 \mathrm{~h} \mathrm{LC}_{50}$ of $H$. elegans larvae were estimated at 0.161 and $0.311 \mathrm{mg} \mathrm{O}_{2} \mathrm{l}^{-1}$, respectively.

\section{Expt 3: swimming velocity of larvae under hypoxia}

All swimming parameters (VCL, VSL and VAP) increased at low DO levels, for DO 2 significantly higher than for DO 6 (Fig. 4). 


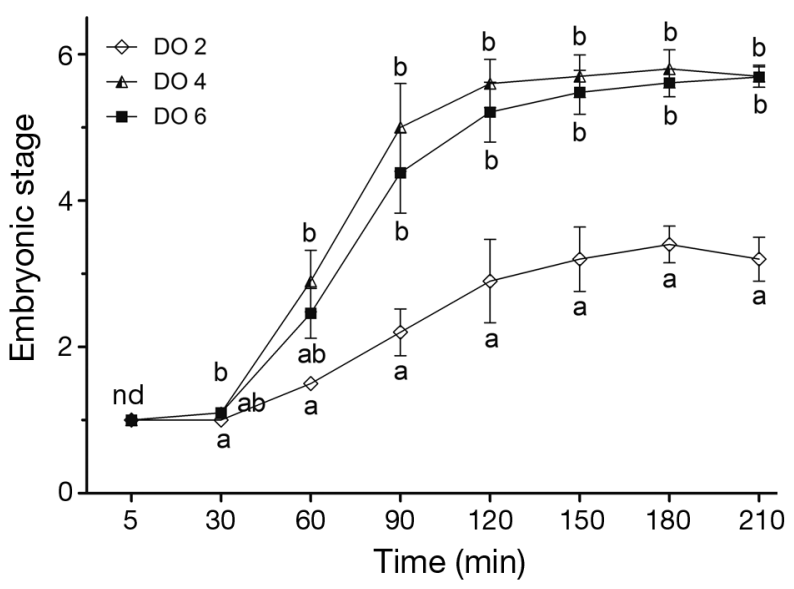

Fig. 2. Hydroides elegans. Effect of reduced dissolved oxygen concentration (DO, $\mathrm{mg} \mathrm{O}_{2} \mathrm{l}^{-1}$ ) on the developmental rate (mean $\pm \mathrm{SD}, \mathrm{n}=5$ ) of embryos, indicated by embryonic stage. The same letters at each sampling time indicate no significant difference according to Kruskal-Wallis test at $\mathrm{p} \leq$ 0.05. nd: no significant difference

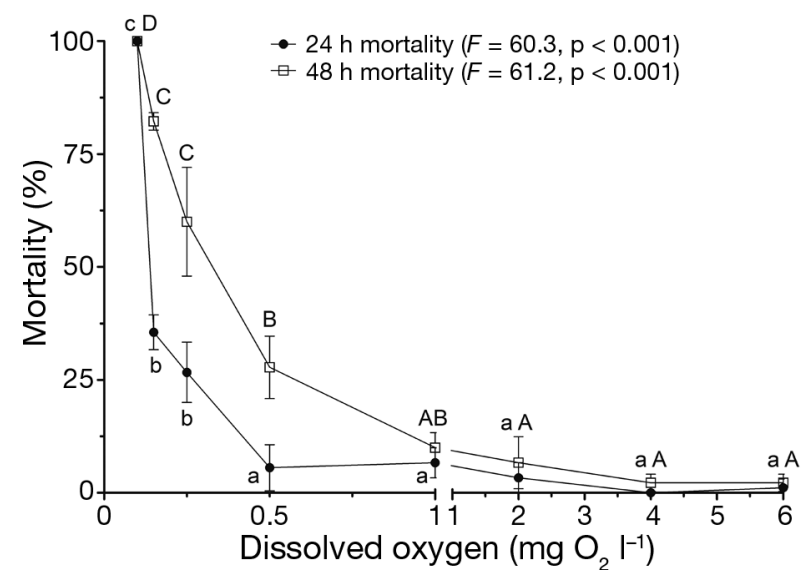

Fig. 3. Hydroides elegans. Effect of reduced dissolved oxygen concentration (DO, mg $\mathrm{O}_{2} \mathrm{l}^{-1}$ ) on the mortality (mean \pm $\mathrm{SD}, \mathrm{n}=3$ ) of larvae after 24 and $48 \mathrm{~h}$ exposure. The same letters at each sampling time indicate no significant difference according to 1 -way ANOVA $(\mathrm{p} \leq 0.05)$

\section{Expt 4: hypoxia tolerance of adults}

The 24 and $48 \mathrm{~h}$ mortalities of adult Hydroides elegans at different DO levels are shown in Fig. 5. Mortality was not significantly different among various DO levels between 6 and $0.75 \mathrm{mg} \mathrm{O}_{2} \mathrm{l}^{-1}$ at $24 \mathrm{~h}$ and between 6 and $1.5 \mathrm{mg} \mathrm{O}_{2} \mathrm{l}^{-1}$ at $48 \mathrm{~h}$. Mortality was higher when the DO level was further reduced, and highest for $0.14 \mathrm{mg} \mathrm{O}_{2} \mathrm{l}^{-1}$ at 24 and $48 \mathrm{~h}$. The $24 \mathrm{~h}$ $\mathrm{LC}_{50}$ and $48 \mathrm{~h} \mathrm{LC}_{50}$ of adult $H$. elegans were estimated at 0.317 and $0.452 \mathrm{mg} \mathrm{O}_{2} \mathrm{l}^{-1}$, respectively. $H$. elegans larvae, therefore, were more tolerant to

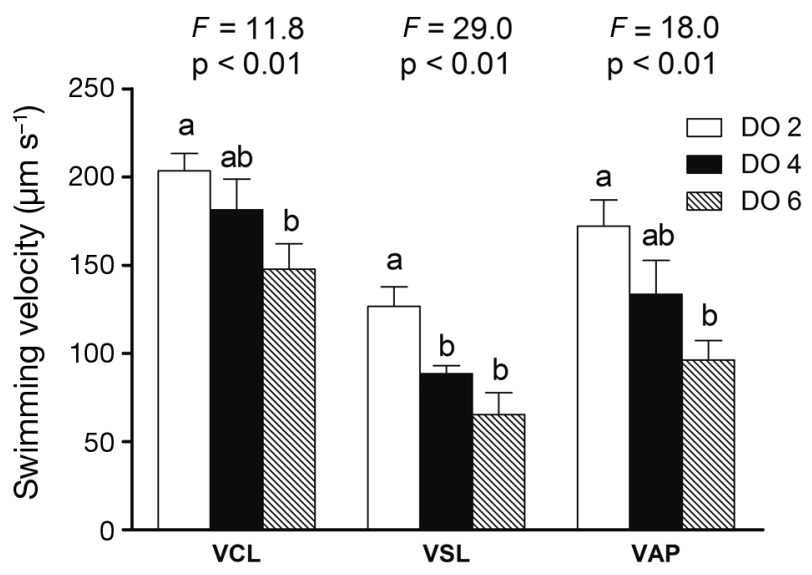

Fig. 4. Hydroides elegans. Effect of reduced dissolved oxygen concentration (DO, mg $\mathrm{O}_{2} \mathrm{l}^{-1}$ ) on the motility of larvae, indicated by swimming velocities VCL, VSL and VAP (see 'Materials and methods, Expt 2'; mean $+\mathrm{SD}, \mathrm{n}=3$ ). The same letters within each velocity indicate no significant difference according to 1 -way ANOVA ( $p \leq 0.05)$

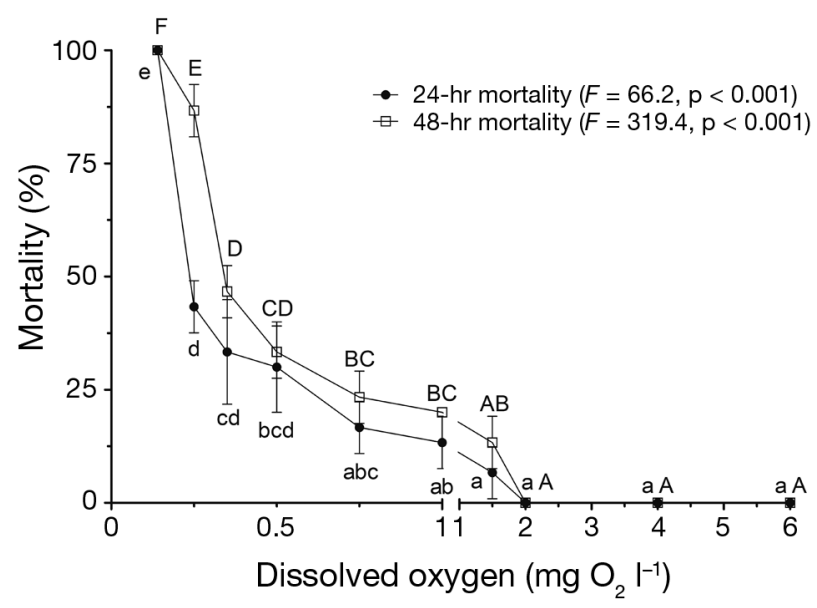

Fig. 5. Hydroides elegans. Effect of reduced dissolved oxygen concentration (DO, $\mathrm{mg} \mathrm{O}_{2} \mathrm{l}^{-1}$ ) on the mortality (mean \pm $\mathrm{SD}, \mathrm{n}=3$ ) of adult $H$. elegans after 24 and $48 \mathrm{~h}$ exposure.

The same letters within each time indicate no significant difference according to 1-way ANOVA ( $p \leq 0.05)$

hypoxia than the adults were, as indicated by the lower values of $24 \mathrm{~h} \mathrm{LC} 50$ and $48 \mathrm{~h} \mathrm{LC}_{50}$.

\section{Expt 5: respiration rate of adults under hypoxia}

Respiration rate was significantly affected by DO level, time and the interaction between DO level and time (Fig. 6). From Day 1 to Day 2, the respiration rate decreased drastically when the DO level was reduced from $6 \mathrm{mg} \mathrm{O}_{2} \mathrm{l}^{-1}$ to either 4 or $2 \mathrm{mg} \mathrm{O}_{2} \mathrm{l}^{-1}$. A 


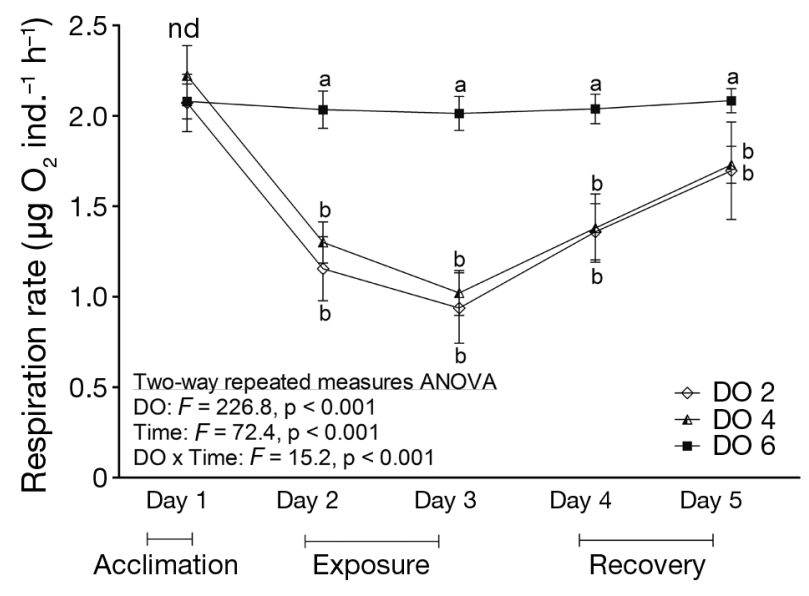

Fig. 6. Hydroides elegans. Effect of reduced dissolved oxygen concentration (DO, $\mathrm{mg} \mathrm{O}_{2} \mathrm{l}^{-1}$ ) on the respiration rate (mean $\pm \mathrm{SD}, \mathrm{n}=6$ ) of adult $H$. elegans from Day 1 to Day 5 . The DO level was re-established at $6 \mathrm{mg} \mathrm{O}_{2} \mathrm{l}^{-1}$ for DO 2 and DO 4 treatments from Day 4 onward. The same letters within each day indicate no significant difference according to 1-way ANOVA ( $p \leq 0.05)$. nd: no significant difference

further decrease in respiration rate was observed on Day 3 for the DO 2 and DO 4 treatments. When the DO level returned to normal (i.e. $6 \mathrm{mg} \mathrm{O}_{2} \mathrm{l}^{-1}$ ) from Day 4 onward, the respiration rate increased gradually. Except for Day 1, respiration rate was significantly higher for the DO 6 treatment than for the DO 2 and DO 4 treatments on all sampling days, while no significant difference was found between DO 2 and DO 4 throughout the experiment.

\section{Expt 6: clearance rate of adults under hypoxia}

The clearance rate was significantly affected by DO level, time, and the interaction between DO level and time (Fig. 7). On Day 2 and Day 3 when the DO level was reduced to 4 or $2 \mathrm{mg} \mathrm{O}_{2} \mathrm{l}^{-1}$, clearance rate decreased significantly, with values obtained for DO 6 significantly higher than those for DO 4 and DO 2. The values for DO 4 were also significantly higher than those for DO 2. When the DO level returned to normoxia from Day 4 onward, the clearance rate of $H$. elegans immediately returned to the normal level for DO 4 , but the recovery was less for DO 2.

\section{DISCUSSION}

The rate of embryonic development of Hydroides elegans under normoxia was similar to that obtained by Gopalakrishnan et al. (2006) in similar experi-

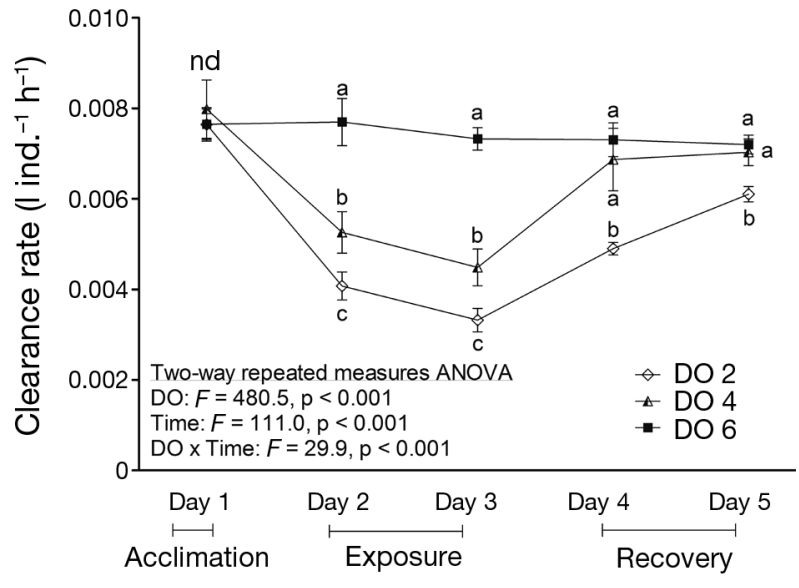

Fig. 7. Hydroides elegans. Effect of reduced dissolved oxygen concentration ( $\mathrm{DO}, \mathrm{mg} \mathrm{O}_{2} \mathrm{l}^{-1}$ ) on the clearance rate (mean $\pm \mathrm{SD}, \mathrm{n}=6$ ) of adult from Day 1 to Day 5. The DO level was re-established at $6 \mathrm{mg} \mathrm{O}_{2} \mathrm{l}^{-1}$ for DO 2 and DO 4 treatments from Day 4 onward. The same letters within each day indicate no significant difference according to 1-way ANOVA ( $p \leq 0.05)$. nd: no significant difference

ments. Those eggs that did not develop into the 2 cell stage were either unfertilized or failed to cleave. Our study did not allow to distinguish between the success of fertilization and cleavage. For species that do not display a fertilization membrane, such as polychaetes, fertilization success can be assessed by the ability of eggs to cleave (Qiu \& Qian 1997). However, in an experiment in which the effect of reduced salinity on sperm motility and cleavage in $H$. elegans was determined separately, both parameters were compromised at reduced salinity (Pechenik et al. 2007). Hypoxia probably affected sperm motility by reducing energy metabolism. Wu et al. (2003) demonstrated that the sperm motility of common carp Cyprinus carpio was significantly impaired when exposed to hypoxia, leading to reduced fertilization success (Kime \& Nash 1999).

The rate of embryonic development in Hydroides elegans was reduced for DO 2. From 150 min onward, the relative proportion of different embryonic stages remained unchanged for DO 2, indicating that the embryonic development from the 1 cell stage to the 16 cell stage was arrested almost completely. The proportion of blastula during this period also remained unchanged because several embryonic stages were pooled. In fact, the proportion of embryos at later differentiated stages increased with time. To observe the fate of those arrested embryos, observations continued for an additional $270 \mathrm{~min}$ after the experiment. Some of the arrested embryos shrank or even burst, suggesting that hypoxia might jeopardize the eggs and 
induce apoptosis or necrosis. It may be that the ATPdependent mitosis was inhibited under hypoxia (Teichner et al. 2011). Even if anaerobic respiration sets in, the limited ATP generated may not be able to support mitosis until hatching. Oxygen supply is welldocumented as a limiting factor for embryonic development in marine invertebrates, including gastropods (Strathmann \& Strathmann 1995, Chan et al. 2008), mussels (Wang \& Widdows 1991) and barnacles (Lucas \& Crisp 1987). The developmental rate of 3 species of opisthobranch gastropods was retarded for embryos exposed to oxygen below 10\% air saturation (Strathmann \& Strathmann 1995). The median hatching time of the embryos of an intertidal prosobranch gastropod Nassarius festivus increased by 24 and $98 \%$ when oxygen levels were reduced to 3 and $1.5 \mathrm{mg} \mathrm{O}_{2} \mathrm{l}^{-1}$, respectively (Chan et al. 2008).

The size of the larvae at hatching was independent of oxygen level in Hydroides elegans, in contrast to smaller larvae hatched at oxygen levels $<3 \mathrm{mg} \mathrm{O}_{2} \mathrm{l}^{-1}$ for the nassariid gastropod Nassarius festivus (Chan et al. 2008). Such differences may be related to their modes of development. Trochophore larvae are present in both gastropods and polychaetes. For prosobranch gastropods, such as $N$. festivus, trochophore larvae develop into veligers inside their egg capsules before hatching. A longer developmental time for veligers than trochophores may amplify the size effect of hypoxia. Trochophores have a less elaborate feeding larval stage than veligers; as such, they may have to reach a critical size at hatching. The present results therefore showed that hypoxia retarded the rate at which the critical size was attained but did not affect the size at hatching.

At reduced oxygen levels, the swimming activity of Hydroides elegans larvae increased, as in gastropod larvae (Chan et al. 2008, Liu et al. 2011). Wu (2002) proposed that the first attempt shown by aquatic species under hypoxia was to maintain oxygen delivery. For example, many fishes under hypoxia increase water flow through the gills (Randall 1982). Similarly, $H$. elegans larvae might raise oxygen delivery under hypoxia by increasing ciliary movement of the prototroch, which might speed swimming up. In addition, increased swimming speed at reduced oxygen levels is considered as an escape response to avoid encountering lethally low levels of oxygen. This response was demonstrated in $H$. elegans as an increase in the dispersal velocity (VSL). This kind of behaviour is also performed by many marine organisms, such as fish, shrimp and gastropod larvae (Chan et al. 2008, Liu et al. 2011), which are able to detect and actively avoid hypoxia by migrating to oxygenated water (Pihl et al. 1991, Wannamaker \& Rice 2000), resulting in an increased chance of survival. When the DO level was reduced further to $<0.5 \mathrm{mg} \mathrm{O}_{2} \mathrm{l}^{-1}$ and approached the lethal limit, the larvae looked languid (Y. S. Leung pers. obs.). This indicated that the reduction in oxygen availability eventually impeded swimming activity.

Hydroides elegans were very tolerant to hypoxia as revealed by $\mathrm{LC}_{50}$ values. This agrees with the conclusion made in a literature review by Gray et al. (2002). High tolerance to hypoxia in polychaetes is attributed partly to anaerobic respiration (Arndt \& Schiedek 1997, González \& Quiñones 2000). When the ambient oxygen level was lowered from $6 \mathrm{mg} \mathrm{O}_{2} \mathrm{l}^{-1}$ to $4 \mathrm{mg} \mathrm{O} \mathrm{O}_{2}$ $\mathrm{l}^{-1}, H$. elegans reduced its oxygen consumption. Further reduction in oxygen level, however, did not change the oxygen consumption. This indicated that $H$. elegans showed conformity at intermediate oxygen levels (between 6 and $4 \mathrm{mg} \mathrm{O}_{2} \mathrm{l}^{-1}$ ) but a good regulatory ability at low oxygen levels between 4 and $2 \mathrm{mg}$ $\mathrm{O}_{2} 1^{-1}$. Similar findings are reported for the polychaete Nereis succinea in tubes (Kristensen 1983), in which regulation of oxygen consumption was partly due to an increase in the duration of ventilation (behavioural regulation) and partly due to increased oxygen extraction (physiological regulation). As we did not record the duration of ventilation (the time the radioles were extended out of the tube) or the water flow rate, the adaptive strategy of $H$. elegans could not be determined, meriting further investigation. Nevertheless, the clearance rate at $2 \mathrm{mg} \mathrm{O}_{2} \mathrm{l}^{-1}$ was significantly lower than at $4 \mathrm{mg} \mathrm{O} \mathrm{O}^{-1}$, indirectly showing that the regulation of oxygen consumption was due to increased oxygen extraction. If a constant respiration rate at reduced oxygen levels is maintained by increasing water flow, the clearance rate should also be independent of oxygen levels or increase at reduced oxygen levels. Constant oxygen consumption with a lower clearance rate when DO was reduced from $4 \mathrm{mg} \mathrm{O}_{2} \mathrm{l}^{-1}$ to $2 \mathrm{mg} \mathrm{O}_{2} \mathrm{l}^{-1}$ indicates that oxygen extraction efficiency increased at reduced oxygen levels. Further, reduction in feeding rate under reduced oxygen levels was reported for other filter feeders, such as oysters (Das \& Stickle 1993). The polychaete Loimia medusa ceases feeding at $<1 \mathrm{mg}$ $\mathrm{O}_{2} \mathrm{l}^{-1}$ (Llansó \& Diaz 1994). As water flow rate was not measured, it is unknown whether the reduction in feeding rate was due to reduction in water flow, or if the feeding time was reduced since $H$. elegans spent more time hiding in the tube under hypoxia (Y. S. Leung pers. obs.). This also partly explained why the oxygen consumption rate decreased when the DO level was reduced from $6 \mathrm{mg} \mathrm{O}_{2} \mathrm{l}^{-1}$ to $4 \mathrm{mg} \mathrm{O}_{2} \mathrm{l}^{-1}$. 
When normoxia resumed on Days 4 and 5, the oxygen consumption and clearance rate of Hydroides elegans increased, but the recovery was incomplete, except for the clearance rate at $4 \mathrm{mg} \mathrm{O}_{2} \mathrm{l}^{-1}$. For the blue mussel Mytilus edulis, 4 patterns of oxygen consumption during the recovery from hypoxia are reported (Bayne \& Livingstone 1977). (1) The classic pattern for the 'repayment' of an 'oxygen debt', oxygen consumption is higher after hypoxia. (2) Oxygen consumption either before or after hypoxia is not significantly different. ( $3 \& 4$ ) Incomplete recovery: the oxygen consumption after hypoxia is suppressed below the values recorded before the reduction of DO levels. The fourth pattern is different from the third one in that oxygen consumption remains extremely low until the DO level increases to levels $>50$ to $60 \%$ of air-saturation. Different recovery patterns are postulated to be related to the accumulation and removal of end products of anaerobiosis (Bayne \& Livingstone 1977). As the accumulation of different end products following anaerobiosis is complex and may involve varied patterns of accumulation in different tissues, it is difficult to explain the recovery process in $H$. elegans without knowing the underlying biochemistry. Nevertheless, a faster recovery of the clearance rate over oxygen consumption indicated different metabolites were involved in these physiological functions. The quick recovery of feeding after hypoxia is adaptive, enabling $H$. elegans to maximise energy intake and compensate for the possible net energy loss during hypoxia.

The bottom waters of the eastern waters in Hong Kong (e.g. Tolo Harbour), where Hydroides elegans were abundant, were hypoxic during summer. In a routine monthly monitoring program conducted by the Environmental Protection Department (http:// epic.epd.gov.hk/ca/uid/marinehistorical/p/1), bottom water in Tolo Harbour, Hong Kong, suffered from hypoxia in summer (July to August) in the past 4 yr between 2008 and 2011. Among the 8 samplings, 4 of them had DO contents of $2.1 \mathrm{mg} \mathrm{l}^{-1}$ or below ( 0.6 to $2.1 \mathrm{mg} \mathrm{l}^{-1}$, or 9 to $31 \%$ saturation). The occurrence of red tides associated with eutrophication also contributes to hypoxia. From 1975 to 2011, 329 cases of red tide were reported in Tolo Harbour, or $37 \%$ of all the cases reported in Hong Kong (www.afcd.gov. hk/english/fisheries/hkredtide/redtide.html). Hypoxia may not have a long-term effect on the larvae of $H$. elegans as most of them could survive for $48 \mathrm{~h}$ at $2.0 \mathrm{mg} \mathrm{O} \mathrm{O}_{2} \mathrm{l}^{-1}$. Considering the mean water depth in Tolo Harbour of $12 \mathrm{~m}$ (Chau \& Jin 1999), and the enhanced swimming speed at $2.0 \mathrm{mg} \mathrm{O}_{2} \mathrm{l}^{-1}$ was $120 \mathrm{um} \mathrm{s}^{-1}$, or $0.43 \mathrm{~m} \mathrm{~h}^{-1}$, it would take only $28 \mathrm{~h}$ for the larvae to escape from hypoxic water and reach the water surface. Nevertheless, polychaete larvae were found to undergo diel vertical migration, with nocturnal ascent and daytime descent to avoid visual predators (Garland et al. 2002). Therefore, they may be exposed to hypoxia during daytime descent. At night, the surface water may also be hypoxic as photosynthesis of phytoplankton is suspended. When the larvae are about to settle and metamorphose, limited swimming power also restricts their ability to escape from hypoxia, not to mention that these developmental processes happen in just a few hours, so intermittent hypoxic events can cause substantial damage to the larvae. Although hypoxia also affected the metabolic rate and feeding rate of the adults, the effect was transient, and individuals recovered quickly when normoxia resumed.

The major effect of hypoxia was on the fertilization and embryonic development. Since the newly spawned eggs of Hydroides elegans are deposited at the bottom, both the embryos and larvae are likely to be exposed to hypoxia in summer. We showed that $\sim 40 \%$ of the eggs did not fertilize or cleave under hypoxia. This would substantially reduce the population of larvae and hence of recruits. Previous studies have demonstrated that the settlement and growth of $H$. elegans is seasonal, occurring only in fall to early spring when the water temperature is relatively low and DO concentration relatively high (Qiu \& Qian 1997, 1998). In summer, when the temperature is high and DO concentration is low, however, the adults suffer from high mortality, and there are no new recruits (J. W. Qiu pers. obs.). Such patterns are interpreted as a result of low salinity in summer as both the embryos and larvae of $H$. elegans are very sensitive to low salinity (Qiu \& Qian 1997). We demonstrated that adult mortality in summer is less likely to be caused by hypoxia unless the water is extremely hypoxic or the duration of hypoxia is prolonged; the lack of summer recruitment, however, is possibly a result of the combined effect of low salinity and hypoxia.

Acknowledgements. Our work was supported fully by a grant from the University Grants Committee of the Hong Kong Special Administrative Region, China (AoE/P-04/04).

\section{LITERATURE CITED}

Arndt C, Schiedek D (1997) Nephtys hombergii, a free living predator in marine sediments: energy production under environmental stress. Mar Biol 129:643-650

Baker SM, Mann R (1992) Effects of hypoxia and anoxia on larval settlement, juvenile growth, and juvenile sur 
vival of the oyster Crassostrea virginica. Biol Bull 182: 265-269

Bayne BL, Livingstone DR (1977) Responses of Mytilus edulis to low oxygen tension: acclimation of the rate of oxygen consumption. J Comp Physiol 114:129-142

Boesch DF (2008) Global warming and coastal dead zones. Nat Wetlands Newsl 30:11-21

- Breitburg DL (2002) Effects of hypoxia, and the balance between hypoxia and enrichment on coastal fishes and fisheries. Estuaries 25:767-781

Carpizo-Ituarte E, Hadfield MG (1998) Stimulation of metamorphosis in the polychaete Hydroides elegans Haswell (Serpulidae). Biol Bull 194:14-24

Chan HY, Xu WZ, Shin PKS, Cheung SG (2008) Prolonged exposure to low dissolved oxygen affects early development and swimming behaviour in the gastropod Nassarius festivus (Nassariidae). Mar Biol 153:735-743

> Chau KW, Jin HS (1999) Depth-averaged, two-dimensional eutrophication modelling for Tolo Harbour, Hong Kong. Environ Model Assess 4:189-199

Coughlan J (1969) The estimation of filtering rate from the clearance of suspensions. Mar Biol 2:356-358

$>$ Das T, Stickle WB (1993) Sensitivity of crabs Callinectes sapidus and $C$. similis and the gastropod Stramonita haemastoma to hypoxia and anoxia. Mar Ecol Prog Ser 98:263-274

> Dauer DM (1993) Biological criteria, environmental health and estuarine macrobenthic community structure. Mar Pollut Bull 26:249-257

> Desai DV, Prakash S (2009) Physiological responses to hypoxia and anoxia in Balanus amphitrite (Cirripedia: Thoracica). Mar Ecol Prog Ser 390:157-166

Diaz RJ, Rosenberg R (1995) Marine benthic hypoxia: a review of its ecological effects and the behavioural responses of benthic macrofauna. Oceanogr Mar Biol Annu Rev 33:245-303

> Diaz RJ, Rosenberg R (2008) Spreading dead zones and consequences for marine ecosystems. Science 321:926-929

EPD (2007) Annual marine water quality reports 2003-2007. Environmental Protection Department, Hong Kong SAR Government, Hong Kong

> Garland ED, Zimmer CA, Lentz SJ (2002) Larval distributions in inner-shelf waters: the roles of wind-driven cross-shelf currents and diel vertical migrations. Limnol Oceanogr 47:803-817

> Godwin LS (2003) Hull fouling of maritime vessels as a pathway for marine species invasions to the Hawaiian Islands. Biofouling 19:123-131

González RR, Quiñones RA (2000) Pyruvate oxidoreductases involved in glycolytic anaerobic metabolism of polychaetes from the continental shelf off central-south Chile. Estuar Coast Shelf Sci 51:507-519

Gopalakrishnan S, Thilagam H, Sellappan M, Vivek Raja P (2006) Larval development and settlement of a marine biofouling organism. In: Kathiroli S, Venkatesan R, Murthy PS, Misra P, Vedaprakash L (eds) International conference on recent advances in marine antifouling technology. Allied, New Delhi, p 430-440

Gray JS, Wu RSS, Or YY (2002) Effects of hypoxia and organic enrichment on the coastal marine environment. Mar Ecol Prog Ser 238:249-279

Henderson SY, Strathmann RR (2000) Contrasting scaling of ciliary filters in swimming larvae and sessile adults of fan worms (Annelida: Polychaeta). Invertebr Biol 119:58-66 Kime DE, Nash JP (1999) Gamete viability as an indicator of reproductive endocrine disruption in fish. Sci Total Environ 233:123-129

Kristensen E (1983) Ventilation and oxygen uptake by three species of Nereis (Annelida: Polychaeta). I. Effects of hypoxia. Mar Ecol Prog Ser 12:289-297

Liu CC, Chiu JMY, Li L, Shin PKS, Cheung SG (2011) Respiration rate and swimming activity of larvae of two subtidal nassariid gastropods under reduced oxygen levels: implications for their distributions in Hong Kong waters. Mar Pollut Bull 63:230-236

Llansó RJ (1992) Effects of hypoxia on estuarine benthos: the lower Rappahannock River (Chesapeake Bay), a case study. Estuar Coast Shelf Sci 35:491-515

Llansó RJ, Diaz RJ (1994) Tolerance to low dissolved oxygen by the tubicolous polychaete Loimia Medusa. J Mar Biol Assoc UK 74:143-148

> Lucas M, Crisp D (1987) Energy metabolism of eggs during embryogenesis in Balanus balanoides. J Mar Biol Assoc UK 67:27-53

> Nestlerode JA, Diaz RJ (1998) Effects of periodic environmental hypoxia on predation of a tethered polychaete, Glycera Americana: implications for trophic dynamics. Mar Ecol Prog Ser 172:185-195

Nilsson HC, Rosenberg R (1994) Hypoxic response of two marine benthic communities. Mar Ecol Prog Ser 115: 209-217

Nixon S (1990) Marine eutrophication: a growing international problem. Ambio 19:101

> Pechenik JA, Pearse JS, Qian PY (2007) Effects of salinity on spawning and early development of the tube-building polychaete Hydroides elegans in Hong Kong: not just the sperm's fault. Biol Bull 212:151-160

Pihl L, Baden SP, Diaz RJ (1991) Effects of periodic hypoxia on distribution of demersal fish and crustaceans. Mar Biol 108:349-360

Pihl L, Baden SP, Diaz RJ, Schaffener LC (1992) Hypoxiainduced structural changes in the diet of bottom-feeding fish and crustacean. Mar Biol 112:349-361

Qiu JW, Qian PY (1997) Combined effects of salinity, temperature and food on early development of the polychaete Hydroides elegans. Mar Ecol Prog Ser 152:79-88

Qiu JW, Qian PY (1998) Combined effects of salinity and temperature on juvenile survival, growth and maturation in the polychaete Hydroides elegans. Mar Ecol Prog Ser 168:127-134

Rabalais NN, Turner RE, Wiseman WJ (2002) Gulf of Mexico hypoxia, a.k.a. 'the dead zone'. Annu Rev Ecol Syst 33: 235-263

Randall DJ (1982) The control of respiration and circulation in fish during exercise and hypoxia. J Exp Biol 100:275-288

Rosenberg R, Loo LO (1988) Marine eutrophication induced oxygen deficiency: effects on soft bottom fauna, Western Sweden. Ophelia 29:213-225

Rosenberg R, Hellman B, Johansson B (1991) Hypoxic tolerance of marine benthic fauna. Mar Ecol Prog Ser 79: $127-131$

Strathmann RR, Strathmann MF (1995) Oxygen supply and limits on aggregation of embryos. J Mar Biol Assoc UK 75:413-428

> Taylor DL, Eggleston DB (2000) Effects of hypoxia on an estuarine predator-prey interaction: foraging behavior and mutual interference in the blue crab Callinectes sapidus and the infaunal clam prey Mya arenaria. Mar Ecol Prog Ser 196:221-237

Teichner A, Eytan E, Sitry-Shevah D, Miniowitz-Shemtov S, 
Dumin E, Gromis J, Hershko A (2011) p31 comet promotes disassembly of the mitotic checkpoint complex in an ATP-dependent process. Proc Natl Acad Sci USA 108: 3187-3192

Townend J (2002) Practical statistics for environmental and biological scientists. John Wiley \& Sons, Chichester

Townsin RL (2003) The ship hull fouling penalty. Biofouling 19:9-15

UNEP (1991) The state of the world environment. United Nations Environment Programme, Nairobi. Available at http://openlibrary.org/works/OL12259568W/The_state_of _the_world_environment_1991

Editorial responsibility: Pei-Yuan Qian,

Kowloon, Hong Kong, SAR
Wang WX, Widdows J (1991) Physiological responses of mussel larvae Mytilus edulis to environmental hypoxia and anoxia. Mar Ecol Prog Ser 70:223-236

- Wannamaker CM, Rice JA (2000) Effects of hypoxia on movements and behaviour of selected estuarine organisms from the southeastern United States. J Exp Mar Biol Ecol 249:145-163

> Wu RSS (2002) Hypoxia: from molecular responses to ecosystem responses. Mar Pollut Bull 45:35-45

> Wu RSS, Zhou BS, Randall DJ, Woo NYS, Lam PKS (2003) Aquatic hypoxia is an endocrine disruptor and impairs fish reproduction. Environ Sci Technol 37:1137-1141

Submitted: March 5, 2012; Accepted: November 13, 2012 Proofs received from author(s): February 25, 2013 